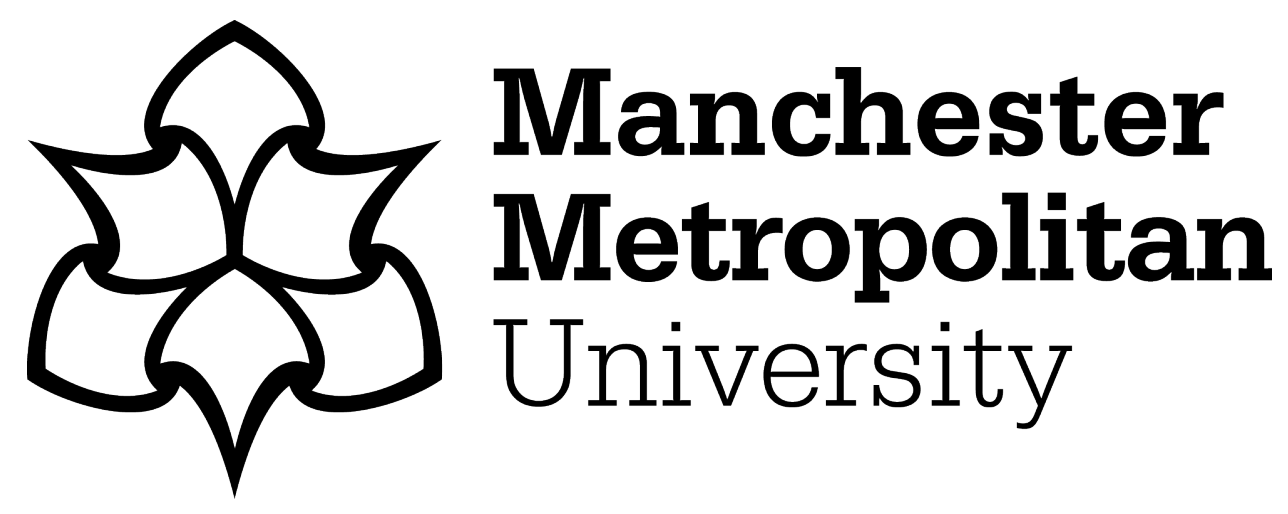

Brahic, Benedicte and Lallement, Maxime (2020) From 'Expats' to 'Migrants': strategies of resilience among French movers in post-Brexit Manchester'. Migration and Development, 9 (1). pp. 8-24. ISSN 2163-2324

Downloaded from: https://e-space.mmu.ac.uk/622212/

Version: Accepted Version

Publisher: Taylor and Francis

DOI: https://doi.org/10.1080/21632324.2018.1503486

Please cite the published version 


\title{
From 'Expats' to 'Migrants': strategies of resilience among French movers in post-Brexit Manchester
}

\author{
Benedicte Brahic \& Maxime Lallement
}

\section{ABSTRACT}

As European citizens residing in the United Kingdom, French nationals enjoy rights of free movement and settlement in their host country, which enables and eases life across borders. In addition to minimal migratory restrictions offered by the European Union to its citizens, the majority of French nationals living in the United Kingdom have a positive and privileged experience as 'movers', feeling welcome and valued in their country of residence. The onset of the Brexit process poses a threat to the rights of free movements for EU citizens and marks the advent of an 'openly admitted' antimigration climate in the United Kingdom; both have direct implications for movers to the United Kingdom. Based on a series of participant observations and semi-structured interviews, this article explores the reactions, responses and strategies displayed and formulated by French movers in the wake of the Brexit process. This paper participates to the exploration of the complex interactions between the global and the local, the political and the personal. The present study endeavoured to question the meaning of the concept of resilience and the realities it assumes for this once relatively privileged group of movers confronted to sudden and unexpected political change threatening their cross-border lives.

KEYWORDS: Brexit, intra-European migration, EU movers, resilience

\section{Introduction}

On 23 June 2016, 51.9\% of the voters who took part in the UK-EU membership referendum (also known - and herein referred to - as the Brexit referendum) voted to leave the European Union. Evidence suggests that rather than solely focussing on the United Kingdom's EU membership, the Brexit vote forms part of a tapestry of nationalist and protectionist responses to the effects of neoliberal globalisation (Coyle, 2016). The Brexit process has direct implications for the 3.6 million EU nationals living in the United Kingdom (Hawkins, 2017) as they derive their rights to migrate and remain in the United Kingdom from EU treaties granting free movement and residency to EU nationals within the European Union. The question of the future of EU nationals living in the United Kingdom has been an anxious one among EU migrant communities in the United Kingdom and, whilst it has rapidly become central in the Brexit negotiations between the British government and the European Union (leading several observers to view EU migrants in the Unites Kingdom as 'bargaining chips' in the Brexit negotiations (Bock, 2017. Based on a series of participant observations supplemented by 15 in-depth semi-structured interviews with French nationals living in Manchester, this paper explores the impact of the ongoing Brexit negotiations on these migrants' lives. As French (and European) citizens, these migrants have insofar enjoyed rights of free movement within the European Union as well as the indefinite right to remain in the EU country of their choice. Benefitting from rights of free movement set intra-EU migrants aside from other 
migrants (who are often subjected to restrictive migration policies) - both in terms of their experiences and in terms of (category of) analysis. This led Favell (2003) to coin the term 'mover' to refer to intra-EU migrants and capture the specificity of their migratory trajectories and experiences. This should not however suggest that movers form a homogenous category. Whilst (post-2004 EU enlargement) Eastern European migrants often encounter discrimination and prejudice in the United Kingdom, Northern and Western European nationals living in the United Kingdom tend to be regarded more positively and have insofar occupied a privileged position in the British migration landscape (both in terms of their legal status and their 'acceptance' by the host population). This may be even more marked for French nationals living in the United Kingdom as the UK's geographical proximity with France (and the many exchanges it has historically fostered and still fosters) and the 'prestige' often associated with French culture by part of the British population confer French movers a privileged position in the United Kingdom. French movers residing in the United Kingdom tend to be regarded as 'desirable migrants'. These factors coupled with a relatively dynamic job market have contributed to make the United Kingdom an attractive destination for French nationals living abroad. With an estimated 250,000-300,000 French residents (The Local France, 2016) the United Kingdom currently hosts the third largest cohort of French nationals living abroad (France Diplomatie, 2017).

As the Brexit vote took place relatively recently (in June 2016) and the process it triggered is still ongoing, there are - to our knowledge, at the time of writing - no scientific data available concerning the attitudes of EU nationals living in the United Kingdom regarding the Brexit process. The Office for National Statistics reports a sharp rise in the number of EU nationals leaving the United Kingdom since the Brexit referendum (a phenomenon often referred to as 'Brexodus' in the press). This contributes to net migration to Britain falling by 106,000-230,000 between June 2016 and June 2017 (Travis, 2017). EU migrants are nonetheless still coming to the United Kingdom, though their numbers are down 19\% between June 2016 and June 2017 with the largest falls among French, Germans, Spanish and Poles (ibid). The British media offer some insights on EU migrants' views and attitudes towards Brexit; they have notably reported on migrants' perceptions that Brexit creates a hostile climate for migrants as well as additional uncertainties regarding their legal statuses, their rights to remain in the United Kingdom and their future prospects in general.

Based on French movers' narratives collected as the Brexit process unfolds (and rights of free movement are under threat), the article explores the reactions, responses and strategies formulated and displayed by movers as the unfolding Brexit process brings uncertainty and growing precarity in their hitherto privileged life across borders. The present study endeavours to question the meaning of the concept of resilience and the realities it assumes for this once relatively privileged group of movers confronted to sudden and unexpected political change threatening their cross-border lives. The article is structured as follows. Drawing from selected contributions concerned with the notion of resilience, the first section seeks to locate the present study within contemporary debates concerned with the precarisation of migration and the lived strategies of resilience, which emerge in response to growing uncertainties and anxieties. The second section of this paper presents key information about the research methods and sample used to generate the data on which this paper is based. The following sections present and interpret the data collected regarding the reactions, responses and strategies displayed by French movers living in the United Kingdom in the wake of the Brexit process before the conclusion returns to the question of movers' resilience in uncertain times. 


\section{Literature review: resilience in the age of global precarity}

This article explores the reactions, responses and strategies formulated and displayed by French movers in Manchester as the unfolding Brexit process brings uncertainty and growing precarity for European nationals residing in the United Kingdom. The present study endeavours to question the meaning of the concept of resilience and the realities it assumes as a tool for social agency and resistance of migrants against precarity.

The concept of resilience has recently been gaining increasing popularity in human sciences. First, inherited from the fields of biology and ecology (Stockholm Resilience Centre), it characterises the ability for a body or an organism to respond to disturbance or environmental change by resisting to damage and increasing the speed and strength of its recovery. On a wider scale, it corresponds to the capacity of life to adapt, develop and strive in spite of accidental and adverse conditions. The progression of the concept of resilience from hard sciences to human sciences proceeds from what scholars have called 'the biologisation of life' (Reghezza, 2017) and belongs to a mode of thinking which Michel Foucault had, in 1978, identified for the decades to come when he defined the modern and postmodern epistemological frameworks as the ones of 'bio-power' and 'biopolitics' (Combes \& Stengers, 2011 ; Mavelli, 2017). Beyond the question of the relevance of this diagnosis, it is the cross-disciplinary proliferation of the use of the concept of resilience in migration studies, which strikes us to be of specific interest for the purpose of this article. In times of growing political and economic instability, the narrative involving the concept of resilience keeps expanding, yet losing lexical precision at equal speed. Our present purpose is to attempt and restore some conceptual clarity whilst eliciting the epistemological and sociological implications of its uses.

The theme of the precariousness of human life (understood from the perspective of lived experience and narrative) has been recently revived by the decision of the British people to leave the European Union following the referendum held on 23 June 2016. After this unprecedented political decision, shifting lexical choices in the media revealed a societal reality, which seemed to have been either voluntarily ignored or forgotten: so-called expats became 'migrants'. Behind an apparently insignificant choice of words, a telling sociological aspect of modern migration in First World countries had been revealed: the ontological status of people having chosen to live in a different country was affected by a changing political situation. What used to be perceived as a sign of postmodernity and the positive impact of globalisation was now designated negatively. Migrants were no longer modern global citizens supporting open-mindedness, culture sharing and cosmopolitanism but started to be described as aliens in a state of perpetual transition and responsible for growing political and economic concern and uncertainty (Dardot \& Laval, 2016).

Corresponding to such a precarious perception of postmodern citizens, sometimes perceived as assets and sometimes as threats, the concept of 'resilience', equally undefined, subsumes very contrasted and divergent sociological tendencies in the way targeted populations respond to unexpected political events (Hall \& Lamont, 2013) stressed the lack of ontological coherence behind the concept of resilience and Schott (2013) criticised the dialectical paradigm, which discourses and counter-discourses on the question of resilience produce. In this respect, to be 'resilient' is either to oppose a state of adversity by resisting it or accepting changes by becoming flexible and adaptable. Whether the global citizen refuses or adapts to sudden changes in her environment, such a binary approach to the concept of resilience ignores the varied and nuanced experiences of individuals 
whose circumstances and actions have to be grasped in their singularity in order to be explored from a sociological perspective. This is why Walsh-Dilley and Wolford insisted on the need for an approach to the use of resilience that takes into account the lived experience of the subjects involved in such situations.

It is precisely what this article attempts to do, by trying to provide an account of the plurality of ways in which a number of French citizens living in the United Kingdom are responding to and carrying on with everyday life following the result of the Brexit referendum. As demonstrated by Chandler (2014 ), given the variability of answers gathered during the fieldwork, it appears impossible to understand attitudes of resilience either from deductive or inductive approaches. Any systematic approach, which links too hastily the reactions of people under the misleading umbrella concept of neoliberal governmentality, risks to miss what is truly at stake from a sociological point of view when the term 'resilience' is used: ignoring that being resilient presupposes an objectivisation of the concept of life which is precondition of biopolitics and neoliberalism (Dardot \& Laval, 2016).

This important aspect of the problem forces us to question what realities the concept of resilience may cover. On the one hand, it is crucial to problematise the points where the political and subjective spheres do (or fail to) intersect. As Balibar (2004) stressed, transnational citizenship within Europe occurs but is far from being self-evident. This present study questions whether the shift from the subjective to the political and institutional levels is made possible merely through the flexibility of lexis or whether an aesthetic dimension, which begs the question of the meaning of 'belonging', is involved (Varoufakis, 2015 ). In the face of growing socio-economic disparities within the political and institutional boundaries of the European Union (Kogan, Gebel, \& Noelke, 2008 ; Trenz, 2016), studying the shape and form of the reactions of French people living in the United Kingdom post-Brexit referendum discloses a typology beyond the traditional boundaries of academic scholarship and defies taxonomy. As it is the lives of people understood as emotional and aesthetic experiences imbued with a history and narrative(s) that surfaces, we had to place ourselves at the crossroads of disciplines in order to start and make sense of often complex and multiform factors motivating people's decisions. In the fashion of Bifulco (2017), we had to tie individual discourses with the perspective of uncertain and changing personal histories and trajectories.

By confronting subjective discourses to attempt to produce an objective account of what characterises times of political and economic recession within the European Union (Leal \& Rodriguez, 2016 ; Trenz, Ruzza, \& Guiraudon, 2015 ), we saw emerging a variety of testimonies touching upon questions which, once again, defied rigid academic taxonomies. As shown by Tassin (2003) or Nelson (2014), living beyond national boundaries forces to rethink the level at which one can still find a scale at which to make sense of one's life, especially in times of troubled and changing political perspectives. Thus, what some scholars have named 'the common' (Dardot \& Laval, 2016 ; Tassin, 2003) suggests that the lived shared experiences of individuals confronted to uneasy and precarious sociopolitical contexts also display an acute ability to think their status and existence beyond pregiven categories, thus keeping the meaning of politics very much alive. It is from this perspective that a revaluation of the concept of resilience needs producing. This revaluation rejects the postulate according to which the concept of resilience is readily transferable from natural to human sciences without critical, sociological and philosophical transformations. This study proves that the variety and disparity of the data collected challenge the idea that 'social' resilience is an evident and systematic response to sudden variations affecting the milieu in which one lives. Rather, following Canguilhem's perspective (1989), we argue that the plane of interaction between the vital and the social should be understood as a rediscovered capacity to choose and follow innovative life choices. This, as the present study demonstrates, becomes clearly apparent when the choices and 
practices followed by migrants challenge most preconceived expectations (IFRC \& RCS, 2016) and manage to rearticulate atomisation and sense of belonging in many creative ways.

This shows that the concept of resilience, so readily exported from the field of positivistic sciences, misses if unquestioned the potential for political innovation and creativity that lies at its core. Unlike scholars who see in it merely another tool for neoliberal governmentality (Joseph, 2013 ), this present article gives us the opportunity to also shed light on the other side of the coin: it is precisely by showing that existential, social and political responses happen first of all below the level of theoretical conceptualisation that true resilience might indeed happen. The group of participants interviewed, all taken hostage of an unforeseen political decision, show the many ways of approaching, resisting, fighting, avoiding, tolerating, accepting or embracing existential challenges ahead.

\section{Research design and sample}

This article forms part of a wider research project entitled 'living or leaving Brexit Britain: EU migrantsin the new age of migration'. This project seeks to understand the impact of the Brexit process on European movers living in the United Kingdom and explores the responses they formulate in response to the changes taking place. This article is based on a series of participant observations supplemented by 15 interviews with French movers based in Manchester.

As a French national living in Manchester with her husband and children and working as a lecturer in Higher Education, the first author has a long-standing familiarity with the population studied. She carried out a series of 20 participant observations in a Manchester playgroup aimed at Frenchspeaking families. These sessions typically attract 7 or 8 adults (regulars and 'chancers', mainly female French movers-settlers aged between 20 and 45) and their children/the children under their care (aged between 6 months and 10 years old). During these sessions, children and their carers share a reading and engage in free play. Adults accompanying their children often engage in conversation and exchange on various topics. It was particularly interesting to note here that, prereferendum, migration-related conversations were typically concerned with bilingualism and comparing childcare and parenting practices in France and in the United Kingdom. Post-referendum discussions focused on Brexit and its possible consequences. However, as time passed, a form of Brexit 'fatigue' developed and participants progressively re-engaged with previous topics of conversation. Observations served to capture rich 'naturally occurring' data on the studied population's feelings and attitudes regarding the Brexit process. However, as many observations were carried out in the presence of small children, there were interruptions in the conversations and/or participants may only want to reveal so much about themselves in the presence of others. Moreover, as suggested above, the fact that the researcher carrying out the observations is a member of the population studied (with her opinion and her lived experience of the Brexit process) also needs to be noted here. Conducting semi-structured interviews served to widen participation, explore lesser understood aspects of the topic under scrutiny and offset some of the biases coming with the familiarity the observer had with part of the population studied. 
Fifteen semi-structured interviews were carried out in the summer 2017. The sample (recruited via purposive and snowballing sampling techniques) included eight female and seven male French nationals living in Manchester and who had lived in the United Kingdom for at least 12 months - see note.1)

Aged between 25 and 72 years old, all the respondents were white, middle class and held a higher education degree. Except for two female respondents currently unemployed (out of choice) and one female participant who was retired, all participants were in paid employment. Three were selfemployed. Others held a mixture of part-time or full-time, temporary or permanent positions in a variety of sectors. Eight of the 12 respondents currently in employment were working in their chosen careers. Two were single, one was widowed, the others were in monogamous relationship (heterosexual and homosexual). Nine respondents were in a relationship with a British national and three with a fellow French mover. Seven respondents had children, with five of them having children under the age of 16. Interviews proved useful to understand some of the lesser understood aspects of the question under scrutiny - particularly the rationales behind strategies for resilience formulated by movers. Interviews also enabled researchers to gain a better understanding of the experiences of single and/or partnered childless movers in the Brexit process. Typically lasting for about $45 \mathrm{~min}$, interviews enabled researchers to explore further the rationale behind movers' reactions, responses and strategies in the wake of the Brexit process.

\section{Findings and discussion: reactions, responses and strategies for resilience}

\section{Reactions - 'the night when I saw the shock coming': waking up as a migrant}

This section first discusses the reactions to Brexit before exploring responses and strategies for resilience formulated by French movers living in Manchester. Among the large number of French movers encountered during the data collection phase, only one appeared to look favourably at the prospect of the United Kingdom leaving the European Union. All the others unanimously rejected Brexit - though with different levels of intensity and on different grounds.

With the exception of the mover supporting Brexit (on similar grounds to Lexit supporters - see note 2), all the movers encountered expected Brexit to be potentially damaging for the United Kingdom (economically, politically, socially and culturally): 'Quite frankly, they are shooting themselves in the foot' (Ludivine). Participants also rejected Brexit on ideological grounds. Though with different levels of intensity, all believed in the worthiness of the European Project. Some, like Fabien, had a strong and long-standing conviction in the European project:

Of course, I have always believed in the EU. I have grown in the EU and I have seen it growing (...). The EU is an awesome idea, it is a very clever idea. What proves it has worked is the fact that we have not been at war since 1945. (...) Countries have stopped fighting. Before we often had the Germans in France and vice-versa. 
His testimony echoes that of other respondents in the higher age bracket of the population under scrutiny, particularly those who had witnessed the changes post-1992 with the adoption of the Maastricht Treaty accelerating and deepening European integration. By contrast, younger respondents (and/or those who declared to have a limited interest in politics and current affairs) seem to have discovered their connection with the European Union in the build-up to the referendum and its immediate aftermath:

Interviewer: Did you feel concerned by the EU before the referendum?

Alex: No, not at all. It was not a problem...not a question. It was something I took for granted. When things start to change for real (as a result of Brexit), I will realise the importance of the EU.

Alex's testimony highlights one central aspect to mover's lives across borders (see Recchi \& Favell, 2009): rights to free movements are often taken for granted with limited appreciation of the privileges they grant EU citizens migrating within the European Union. Whilst there seems to be a consensus regarding the impact of Brexit for the United Kingdom and a sense of a heightened attachment to the European Union among movers in these times of uncertainty, the question of their reactions to Brexit and its expected impact on their lives was not as unequivocal.

Since the vote in favour of Brexit in June 2016, the movers encountered have gone through a range of emotions and reactions. Elodie compares her journey post-referendum (and that of fellow movers she knows) to the process of grieving:

It is truly a grieving process ... a grieving process that has been observed in many people. (...) I think it's the process of grieving an idea, an ideal. The European ideal? An integration ideal? (...) The grieving process has different stages. There is shock, anger, depression and sadness, acceptation and bouncing back. I went through all these phases.

Elodie's metaphor has been widely used to characterise the post-referendum experience of Brexit opponents. However, whilst many movers describe similar feelings to Elodie, the metaphor should only be extended with caution. Recent movers and movers who declare themselves flexible (in terms their country of residence) do not seem to have reacted to the outcome of the Brexit referendum as strongly/with the same intensity as movers settled/rooted in Manchester (via their job and or their relationship/family).

Movers who recently arrived in the United Kingdom are still in the process of easing into their new environment and their new life. Whilst they may be in the process of forming attachment to people and places in their new locality, connections with their 'previous' life remain strong and meaningful - their new life being partly interpreted and made sense of in close relation to their past experiences. Being a migrant, identifying as a migrant is still constitutive of their current sense of self 
and their everyday experience. Many movers in this group (in comparison to their more seasoned counterparts) declared they had anticipated the outcome of the Brexit referendum and for those who had not, Brexit was a surprise but not necessarily a shock ('it was a surprise and a disappointment', Ludivine), it did not resonate as personally and intimately as it did for long-term movers. For this latter group, the Brexit vote was a shock:

It was a shock, I stayed up all night. This is forever etched in my memory ... that night when I saw the shock coming. (...) I will never forget this date because it was so important for me. (...) It was a part of me that was ... torn apart, I felt torn apart. (Sandrine)

Many, like Fabien, felt quietly confident that the Remain vote would win:

I was so surprised, very disappointed as well. The day of the result, friends and I had planned to meet in front of the Manchester town hall to celebrate the Remain victory with European flags ... at five in the morning, we had a chat and decided we'd go to bed and would not get the flags out.

The results being so close (51.9\% for leave and $48.1 \%$ for remain, Electoral Commission, 2016), projections could not reliably predict the outcome of the referendum which led many movers to wait until the early hours of the morning for the result to be proclaimed. Interestingly, the fact that the outcome of the referendum was revealed at night - which disrupted habits and/or sleep - bears a special significance for these movers. In their accounts of the referendum, the darkness of the night and the anxieties it can bear echoed the sense that this particular night marked the end of an era and the dawn of unknown and unwanted times.

Regardless of whether or not the outcome of the referendum had been anticipated, all long-term movers remember the shock it was: 'Though I had warning signs, the disappointment was huge. It was a massive shock' (Mireille). Whilst recent and flexible movers did not appear 'to take the vote personally', long-term movers interpreted it differently, often in very personal terms: 'I can't help taking it personally....' (Claire). 'All of a sudden, it made me feel French and no longer accepted' (Caroline). Up until that night, Caroline who had spent more than half of her life in Manchester studying, working and raising a family with an Englishman - felt well integrated in the United Kingdom. The Brexit vote made her feel like a migrant for the first time (in a long time). It gave her the feeling that even though she felt integrated and part of the community, some people did not see her that way. In the United Kingdom, for some, she would always be and had always been a migrant. This impression of rejection felt particularly strong, as apart from some teasing/banter and minor comments (mainly on their French accents), very few French movers had encountered racism and discrimination ('twice in eighteen years I have been in the UK' (Fabien). In that sense, their experience contrasts sharply with that of Eastern Europeans who have been the direct and/or indirect victims of discrimination: 'I was going through what Polish people must have endured for years' (Sandrine). As suggested by Sandrine's testimony, many French nationals living in the United Kingdom described enjoying a privileged position in British society (or at least in the circles they frequent), as they felt their French heritage was valued and celebrated in their host country. Rather 
than 'migrants', many French movers living in the United Kingdom referred to themselves as 'expats' to (often insentiently) differentiate themselves from migrants and as a means to acknowledge their privileged situation in the United Kingdom. With the Brexit process in motion, many feared their privileged life of free movers may be under threat which, in turn, triggered a variety of subtle early responses.

\section{Responses - 'nothing has changed, yet everything has changed': continuity, self-censoring and boomerang isolationism}

Participant observations - and perhaps to a lesser extent, interviews - highlight the existence of a lived Brexit timeline where the shock and anger felt in the beginning give way to a sense of lingering sadness and fatigue (the latter being heightened by the limited visibility in and the lengthiness of the Brexit 'negotiations'). Though when asked, respondents initially declared they had not seen any changes in their daily lives ('I haven't had an impact personally, on my day-to-day life at all', Perrine), other declarations lead to think otherwise. As Elodie pointed out, 'nothing has changed, yet everything has changed'. This section explores aspects of resilience linked with the everyday and continuity, albeit continuity tainted with subtle changes taking place in the wake of the Brexit negotiations.

In the aftermath of the referendum results, many movers - old and new - declared to have taken an accrued interest in politics and current affairs, particularly regarding the European Union and the Brexit process. As illustrated by Ludivine's testimony, before the referendum, several movers used their EU rights of free movement without questioning them, the referendum (and perhaps the fear of losing their rights of free movement and migrant life as they knew it) triggered an interest in the European Union:

for me before the referendum, the EU was something that made my life easier. (...) At the time of the referendum, I started to look into the legal framework, which is something that never interested me before. (...) then I started to understand this machine (the EU), what it can and cannot do. What it should do. So, yes, clearly for me, the referendum radically changed my perception'. (Ludivine)

However, for many, the interest mustered in reaction to the referendum started to wear off and took a more instrumental turn with both long-term and recent movers, flexible and less flexible movers looking - with various degrees of diligence - into the conditions and administrative procedures to be granted permanent residency in the United Kingdom and carry on with their lives (see also following section).

In addition to seeking information about their legal status in the United Kingdom and possible means to ensure they could stay in the United Kingdom, many French movers adopted subtle selfprotection strategies in the weeks following the referendum. As mentioned above, many movers particularly long-term ones - were saddened by the outcome of the referendum and felt rejected 
from and by British society. The surge in the number of racist incidents reported in the media during the weeks following the referendum reinforced the feeling of ostracisation among movers - women with school-age children appeared particularly concerned that their children and themselves may become the target of xenophobic abuse. This led several of these women feeling self-conscious and anxious about speaking French to their children in public places (when they felt neutral or positive about it before). Catherine recalled sitting in the waiting room of her local NHS GP practice with her baby son (whom she would normally address in French), keeping silent and only quietly whispering to him so other patients would not hear she was a foreigner. She would not have 'normally' acted this way but, on that occasion, following the referendum, she was worried that other patients may think she was 'taking their place' and was putting a strain on the NHS (interiorising some of the xenophobic messages of the 'Leave' campaign she had found profoundly distressing). In the same way, Sandrine declared 'I no longer wanted people to hear I was European' (Sandrine). Interestingly, French female mothers fearing verbal abuse were not its recipients. The racist incidents reported in this study had been perpetrated by inebriated strangers in public spaces:

Since Brexit, I have been the victim of three racist incidents directed against me by people who asked me why I was still living here, why I had not already left, and who asked me if I had packed my suitcase. Since the vote, political correctness has disappeared, people are much more aggressive, they feel they can get away with anything. The fact they voted for it and that Brexit won, they feel liberated. (Fabien)

The alleged change of attitude noted in the general population had an impact on the perception of French movers towards their host country - this was mainly noticeable among long-term and less flexible movers. 'I am feeling quite paranoid now (...) After Brexit, I thought people were looking at me funny. What's up? They don't like my accent? They voted "Leave", they want me to leave? I feel more aggressive now' (Elodie). The referendum has instilled a doubt as to whether people around these movers wanted them to stay. The feeling of rejection experienced by some movers led to further rejection on their part: 'When I was in the street, I was looking at people and wondering "Remainer" or "Brexiteer", "Remainer" or "Brexiteer". (...) There is a part of me that no longer likes Britain' (Edith). 'For me, Britain has turned into a nationalist island' (Mireille). Before going any further, it is interesting to note here that many respondents took comfort in the fact that the majority of voters in Manchester voted to remain in the European Union and/or that contact with Brexit voters was deemed only occasional. 'I only feel a bit scarred when workmen come to cut a tree next to my house' (Sandrine). The classist undertone of Sandrine's comment inadvertently reveals her representation of the Brexit vote as confined to specific sections of the population from which she feels separated. However, if the Brexit vote brought distance and division between movers and members of the general public, it proved particularly hurtful when similar feelings occurred between close friends and family members. 'I nearly ended some friendships as they (friends) had talked abruptly about Brexit and were treating me like a foreigner when, up until now, I had always been a friend' (Edith). Similarly, Caroline and her British husband struggled to come to terms with the fact that his parents/her parents-in-law had voted in favour of Brexit. In response to their perceived exclusion, some movers started to make less effort to develop new contacts and maintain friendships with locals ('I no longer try to make friends. If someone talks to me, fine but if not, I won't be starting the conversation. It does not interest me anymore. They do not interest me anymore' [Elodie] - the generalisation of the 'they' is symptomatic of the rupture described). In a bid to counteract ostracisation, some movers (particularly female ones with children) started to invest 
more time and effort with fellow (groups of) nationals: 'it is a space to talk, a safe space to talk where we can share and express how we feel' (Melanie). French-language Saturday schools and French-language playgroups have doubled-up as informal support groups where movers could talk, ask questions and share tips. Feelings of exclusion and resentment following the referendum rapidly bred isolationist tendencies and boomerang racism among movers, many of whom seem to have started to mentally prepare to detach themselves from UK society should it become necessary in the future.

\section{Strategies: 'in the short term, nothing has changed, in the long term, everything has changed'}

Despite not perceiving the onset of the Brexit process (which officially started on the 29 March 2017 when Prime Minister Theresa May triggered Article 50) as putting their way of life under immediate threat, all the movers encountered have nonetheless considered possible strategies to maintain their current way of life and/or to devise alternative ones. The strategies formulated capitalise on what respondents understand to be resources for and sources of resilience. Degrees of flexibility in the personal and professional realms (movability) informed the strategies (of continuity and/or change) formulated by movers. Unspoken yet noticeable gender dynamics were also at play. Before going any further, it is interesting to note here that a mixture of confusion, pro-activity and apathy accompanied the formulation of the strategies. This mixture of attitudes needs to be read in the current context of the ongoing Brexit negotiations which allow no visibility to EU migrants and their families with new developments (actual or supposed) emerging on an almost daily basis.

Apart from one respondent who had resolved to leave the United Kingdom following the outcome of the Brexit vote, all the participants encountered declared they would like to stay in Manchester. Whilst for some, 'staying in Manchester (or in the UK)' was their preferred option, for others, it was regarded as their sole option. These participants understood their current lives as non-movable. The case of Pascal, a local business owner, illustrates the strategies for resilience devised by single individuals whose assets and source of income are tied to the United Kingdom/Manchester. For Pascal, leaving the United Kingdom is not an option; this prompted him to apply for permanent residency in the immediate aftermath of the Brexit referendum. He diligently completed the infamous 80-page document (which was eventually streamlined before the scheme was taken down). Once granted permanent residency, Pascal applied for British citizenship, which he obtained within 15 months of the Brexit referendum. Though he was concerned that his parents might be upset about it, becoming British made his future in the United Kingdom 'Brexit-proof'. Movers like Pascal - single, yet not professionally flexible - felt exposed by the possible changes to their migratory status brought about by the Brexit process. They felt they were on their own (i.e. no partner and/or family in the United Kingdom) and could not call upon external sources of resilience. Strategies for resilience sought to maintain continuity and consisted in making plans to protect assets and sources of income.

Similarly, several respondents - typically female and in a relationship with an English male partner felt that leaving Manchester was not an option however for very different reasons linked to their family life in Manchester. These women believed that their partner (typically the highest earner in 
the couple) would struggle to move outside the United Kingdom and continue working in their current career and/or maintain their current level of earnings. As British nationals, their partners would also potentially face the same limitations as them if they were to move to one of the EU member-states. They also felt their children were 'settled' and moving overseas would potentially be disruptive for them. Interestingly, though they wanted to stay in Manchester, none of these women had taken concrete steps to secure permanent residency: 'I downloaded the application for permanent residency but I have not filled it in yet. I was about to do it but, at the last minute, I thought to myself, this is all a bit hypocritical, I already reside here!' (Sandrine). Caroline was advised to take British citizenship to protect her life with her family in Manchester; however, she cannot resolve to apply: 'I did not come to England to be British. I am European, I am 100\% Europe. The only thing is that if it has a big impact on my daughters ... we will see'. Women married to their British partner appeared quietly confident that they would not be 'thrown out of the country': 'I think ... the fact that my husband has a British passport, I think that whatever will happen I might be safe. I believe that they're not gonna kick out all Europeans, I hope so, so I think that I'm fine' (Perrine). Unmarried female movers contemplated marriage as a possible way to secure their future in the United Kingdom. Whilst these women believed, they would be granted the right to stay in the United Kingdom on family-related grounds, they seemed concerned about the impact Brexit may have on their life and their work prospects in the United Kingdom: 'Last year, I started to think I will have to change my name (to her husband's surname only). (...) I am worried that when I apply for jobs, I will pay the price for being French. I don't want to take British citizenship though. I am European' (Caroline). Interestingly, though reasserting their commitment to and love for Europe, none of the respondents had sought to establish contacts with organisations lobbying for the United Kingdom to stay in the European Union and/or to uphold the rights of EU nationals in the United Kingdom. Thinking about remedial strategies to appease and overcome the divisions revealed by Brexit, Sandrine declared she wanted 'to establish links with Brexiteers. (...) To make progress, I think more of a dialogue with local residents'. The desire for continuity was strong yet no sustained strategies for resilience had been devised and implemented. Participants shared the (unfounded) belief that their family links with a British national would protect them in case of a possible change in their migratory rights.

Although this was not their favourite option, many respondents took comfort in the idea that they could leave the United Kingdom and 'bounce back'. Envisaging a worst case scenario in which they had to leave the United Kingdom and yet imagine ways to construct a new life appear to give these respondents a sense of their own resilience in the face of adverse circumstances. Feeling mobile made them feel resilient which in turn formed part of resilience. Whilst some located sources of resilience within themselves (by being flexible in terms of their jobs and/or its location), others (typically movers in relationships and more frequently female ones) saw strategies for resilience as collectively produced with their partner and/or family. As suggested above, the first category of respondents drew resilience from their own flexibility in terms of their jobs (types of occupation and/or locations). This group included respondents who were highly skilled single movers currently employed in highly skilled jobs (in sectors of activities where they knew their skills were in demand in a variety of locations) or in low-skilled jobs in the service sector. The latter were often female movers who had relatively recently arrived in the United Kingdom; in the future, they were hoping to work in their preferred sector of activities at the level of qualification they had achieved. It is interesting to note here that, although they would prefer to stay in Manchester for the foreseeable future, they were willing to envisage as a source of opportunities. 
Being single, I am ready to go somewhere else and I must admit I am looking (for jobs) in other places. If there is an opportunity to go to Canada - a country I love where I have many friends - I will go to Canada, no problem. [...] Yes, Brexit really changed the future I had planned (...) I have been here for twelve years and I used to see myself staying in Manchester until I am 60, (...) In the short term, nothing has changed, in the long term, everything has changed.

In his interview, there was a clear sense that Fabien's experience in Manchester may be drawing to a close. Whilst he admits to feel sad about Brexit and the prospect of leaving Manchester, he finds resilience in exploring possible opportunities, which may arise with this change.

By contrast, movers in relationship and/or having children with their partner described exit strategies for resilience as collectively produced with their partners and/or relatives. Half of the respondents devising exit strategies together with their partner (and families) were in relationship with fellow French movers or - in lesser proportion - with fellow foreigners. The remainder were in relationships with British nationals who had lived abroad in the past and/or had an appetite to live overseas. In their cases, the availability of cosmopolitan capital informed the strategies devised. Women often appeared to be more flexible than their partners were. Marina who is currently staying at home to raise her children will 'follow' her partner (the sole breadwinner) wherever works takes him. These gendered patterns based on traditional gender roles were also observable among (childless) working couples. Laure is a qualified environmental planner; her partner is an engineer. Proving herself resilient in the face of adversity, she jokingly declared: 'we will Brexit ourselves, ourselves!' Their agreed plan was for him to find a job in his sector of activity first and she will follow him wherever he goes. She believed it would be easier for her to find work in the environmental sector but she was also willing to 'change careers again ... many women do!' Whilst Brexit brings uncertainty in these movers' lives, female movers seemed more at risk (than their male counterparts) to have to relent on their current lifestyle (see also Duda-Mikulin, this issue).

\section{Conclusion}

As European citizens moving to the United Kingdom, French nationals currently enjoy rights of free movement and settlement in their host country, which enables and eases life across borders. In addition to minimal migratory restrictions offered by the European Union to its citizens, the majority of French nationals living in the United Kingdom have a positive and privileged experience as 'movers', feeling welcome and valued in their country of residence. The onset of the Brexit process poses a threat to the rights of free movements for EU citizens and marks the advent of an 'openly admitted' anti-migration climate in the United Kingdom; both have direct implications for movers to the United Kingdom. Based on a series of participant observations supplemented by 15 semistructured interviews, this article explores the reactions, responses and strategies displayed and formulated by French movers in the United Kingdom in the wake of the Brexit process. Though it focuses on the impact of a localised event - the Brexit vote in the United Kingdom - on a specific group of migrants, this paper participates to the exploration of the complex interactions between the global and the local, the political and the personal. Furthermore, the present study endeavoured 
to question the meaning of the concept of resilience and the realities it assumes for this once relatively privileged group of movers confronted to sudden and unexpected political change threatening their cross-border lives.

The fieldwork conducted and its analysis revealed various trends, which start to form a picture accounting for the versatility of a variable concept. The majority of respondents reacted to the outcome of the referendum with vivid emotion. Even though the very nature of this emotion changes from person to person, it appears that most interviewees admitted having been either taken by surprise or shocked by the referendum result. However, this study shows that the initial reaction is not necessarily followed by a response and/or the formulation of a strategy for resilience. A lot of respondents directly or indirectly showed signs of 'Brexit fatigue', admitting having been upset at first yet showing at the same time some signs of distancing from the original upheaval. This tendency can be accounted for by two main factors: the first being the lack of visibility caused by a process of negotiations unfolding with great uncertainty, the second leading the respondents to realise that what was at first perceived as a narrowing down of options became, through the force of necessity and facts, a source of unexpected possibilities. The latter reveals an aspect of resilience, which densifies its concept. This shows that resilience does not correspond to mere persistence in opposing adverse events but can also bring forward a creative and new outlook upon the situation. However, it is important to note that the degree of flexibility shown by respondents largely depends on their professional and familial situations. Individuals having established a rewarding and meaningful professional environment in the United Kingdom appeared less keen on risking what they seemed to have secured through their labour, and people living with family in the United Kingdom (usually a partner and children) were less prone to react with flexibility. Often putting the interest of the other members of the family first, female respondents often declared that they would follow the course of action which less impacts the lives of their loved ones.

In the same fashion, French migrants having lived in the United Kingdom for a relatively long time seemed less ready to relocate, although this tended to be rather due to professional and/or family limitations than to strict existential or emotional attachment to a specific place or country. Often, the feeling of disappointment occasioned by the failure of the ideals of the European project or by an impression of change concerning the attitude of British nationals towards them motivated the possibility of geographical relocation. However, it is important to note that this feeling of loss of belonging or of rejection often appears to be the fruit of mental projection than the materialisation of actual conflict. If some respondents have noted a change in the behaviours of British nationals towards them, incidents of this kind remained however rare and isolated. Rather, a fear of rejection coupled with a feeling of uneasiness corresponding to the immediate aftermath of the referendum is manifest. This sentiment, following the curve of the 'Brexit fatigue', tends to diminish as time passes and 'things move on'. Be that as it may, a small number of respondents have clearly started to disenfranchise themselves from their host country. This corresponds to a feeling of separation, which is proportional to the importance of the mental projection of the European ideal by protagonists.

Regarding concrete plans and actions taken, the majority of respondents claimed to be 'more or less' aware of what they could and/or should do when the actualisation of Brexit takes place, but very 
few people have actually taken concrete steps to materialise and secure their residence. The motivation for this is not always clearly perceptible, but it appears to have something to do with the feeling that the current negotiations are paralysed and too uncertain. Meanwhile, most respondents use this period of status quo to distance themselves from the concrete, administrative, political and factual reality of Brexit. It seems indeed that for the majority of participants, Brexit remains a sword of Damocles whose fall is unavoidable. In this context, the concept of resilience does not correspond so much to a pre-emptive or proactive strategy but to a resignation through which people eventually confess being ready to do what it takes to secure or stabilise their position when time comes. This shows almost two opposite sides of the reality of resilience but this opposition does not, however, negate the relevance of this concept. Quite the contrary, it reveals the creative dimension at the basis of the lives of resilient migrants. This should however not mask the entrenchment of inequalities - particularly gendered ones - likely to result from the formulation of these resilience strategies.

\section{Notes}

1. The minimum length of residency required for EU citizens to apply for permanent residency remains unconfirmed at the time of writing; however, observers often assume that this period will be 5 years. Whilst two-thirds of the respondents have lived in the United Kingdom for more than 5 years, five participants migrated to the United Kingdom less than 5 years ago - which may have an impact in terms of the status they are granted once Brexit is enacted.

2. Lexit supporters, situated on the Left of the British political spectrum, argue for the exit of the United Kingdom from the European Union as they believe the EU institutions to be inherently undemocratic and prevent member states from transitioning to 'socialist' economies. It is interesting to note that similar ideas were gaining popularity in France during the last Presidential elections (May 2017).

\section{References}

Balibar, É. (2004). We, the people of Europe? Reflections on transnational citizenship. Princeton: Princeton University Press.

Bifulco, A. (2017). Identity. Oxford: Taylor and Francis.

Bock, P. (2017). A year in my life as a Brexit bargaining chip. Retrieved October 9, 2017 from https://www.newstatesman.com/politics/brexit/2017/03/brexit-bargaining-chip-eu-citizens-yearlife 
Canguilhem, G., Fawcett, C. R., Cohen, R. S., Foucault, M., \& Foucault, M., with an introduction by. (1989). On the normal and the pathological. New York: Zone Books.

Chandler, D. (2014). Beyond neoliberalism: Resilience, the new art of governing complexity. Resilience, 2(1), 47-63. [Taylor \& Francis.

Combes, M., \& Stengers, I. (2011). La vie inséparée: Vie et sujet au temps de la biopolitique. Paris: Dittmar.

Coyle, D., (2016). Brexit and globalisation. Retrieved January, 16, 2018 from https://voxeu.org/article/brexit-and-globalisation

Dardot, P., \& Laval, C. (2016). New way of the world: On neoliberal society. London: Verso.

Diplomatie, F. (2017) La communauté française inscrite au registre des Français établis hors de France, France Diplomatie, Retrieved January 16, 2018 from

https://www.diplomatie.gouv.fr/fr/services-aux-citoyens/inscription-consulaire-et-communautefrancaise/article/la-communaute-francaise-inscrite-au-registre-des-francais-etablis-hors-de-france

Duda-Mikulin, E. (in press, this issue). Gendered migrations and precarity in the post-Brexit-vote UK: The case of Polish women as workers and carers. Migration and Development.

Electoral Commission. (2016). EU referendum results. Retrieved October 9, 2017 from https://www.electoralcommission.org.uk/find-information-by-subject/elections-andreferendums/past-elections-and-referendums/eu-referendum/electorate-and-count-information Favell, A. (2003). Eurostars and Eurocities: Towards a sociology of free moving professionals in Western Europe CCIS The Centre for Comparative Immigration Studies .

Foucault, M. (1998). The history of sexuality: The will to knowledge: V. 1: the will to knowledge. London: Penguin Books.

Hall, P. A., \& Lamont, M. (2013). Social resilience in the neoliberal era. Cambridge: Cambridge University Press.

Hawkins, O. (2017). Migration Statistics. Retrieved October 9, 2017 from http://researchbriefings.parliament.uk/ResearchBriefing/Summary/SN06077\#fullreport Jordan, L. (2017). Introduction: Understanding migrants' economic precarity in global cities. Urban Geography, 38(10), 1455-1458.

Joseph, J. (2013). Resilience as embedded neoliberalism: A governmentality approach. Resilience, $1(1), 38-52$.

Kogan, I., Gebel, M., \& Noelke, C. (2008). Europe enlarge: A handbook of education, labour and welfare regimes in central and eastern Europe. London: Policy Press

Le Blanc, G. (2010). Canguilhem et la vie humaine. Paris: Presses Universitaires de France.

Leal, D. L., \& Rodriguez, N. (2016). The new era of restriction. In D. L. Leal \& R. N. Rodriguez (Eds.), Migration in an era of restriction and recession: Sending and receiving nations in a changing global environment (pp. 1-23). London: Springer 
Mavelli, L. (2017). Governing the resilience of neoliberalism through biopolitics. Retrieved July 5, 2017 from

https://www.academia.edu/31229531/Governing_the_resilience_of_neoliberalism_through_biopoli tics

Nelson, S. H. (2014). Resilience and the neoliberal counter-revolution: From ecologies of control to production of the common. Resilience, 2(1), 1-17

Recchi, E., \& Favell, A. (2009). Pioneers of European integration: An introduction. In E. Recchi \& A. Favell (Eds.), Pioneers of European integration: Citizenship and mobility in the EU (pp. 1-25).

Cheltenham: Edward Elgar

Schott, R. M. (2013). Resilience, normativity and vulnerability. Resilience, 1(3), 210-218.

Stockholm Resilience Centre, \& Stockholm Resilience Centre. (2014). What is resilience? What Is Resilience? An introduction to social-ecological research. Retrieved July 5, 2017, from

http://www.stockholmresilience.org/download/18.10119fc11455d3c557d6d21/1459560242299/SU _SRC_whatisresilience_sidaApril2014.pdf

Tassin, É. (2003). Un monde commun : Pour une cosmo-politique des conflits. Paris: Éditions du Seuil.

The Local France (2016) 'Brexit bargaining chips' - French in UK vs Brits in France, The Local France, retrieved January 16, 2018 from https://www.thelocal.fr/20170303/french-expats-vs-british-expatswhos-got-the-bigger-bargaining-chips.

Travis, A. (2017, November 30). Net migration to UK shows largest annual fall since records began. The Guardian, Retrieved January 16, 2018 from https://www.theguardian.com/uknews/2017/nov/30/net-migration-to-uk-shows-largest-annual-fall-since-records-began

Trenz, H.-J. (2016). Narrating European society: Toward a sociology of European integration. London: Lexington.

Trenz, H.-J., Ruzza, C., \& Guiraudon, V. (2015). Europe's prolonged crisis: The making or the unmaking of a political union. London: Palgrave.

Varoufakis, Y. (2015). The global minotaur: America, the true origins of the financial crisis and the future of the world economy. London: Zed Books.

Walsh-Dilley, M., \& Wolford, W. (2015). (Un)Defining resilience: Subjective understandings of "resilience" from the field. Resilience, 3(3), 173-182. 